\title{
PENGARUH KEPEMIMPINAN KHARISMATIK KEPALA SEKOLAH TERHADAP MOTIVASI KERJA GURU SMA ISLAM AL-ASHAR NW KAYANGAN BATU LAYAR KABUPATEN LOMBOK BARAT
}

\author{
Hardiansyah \\ Universitas Pendidikan Mandalika \\ Email : hardiansyah@undikma.ac.id
}

\begin{abstract}
Abstrak: Kebutuhan kajian tentang kepemimpinan dan kinerja guru di tengah-tengah rendahnya kualitas pendidikan di negeri ini masih sangat diperlukan. Kepala sekolah di masa mendatang dituntut mampu menyelaraskan sumberdaya dan potensi sekolah untuk mencapai kinerja yang tinggi menuju kualitas pendidikan yang lebih baik. Untuk itu tujuan penelitianya untuk mengetahui pengaruh kepemimpinan kharismatik kepala sekolah terhadap motivasi kerja guru SMA Islam Al-Ashar NW Kayangan Batu Layar Kabupaten Lombok Barat. Populasi dalam penelitian ini adalah seluruh guru di SMA Islam Al-Ashar NW Kayangan Batu Layar Kabupaten Lombok Barat yang berjumlah 30 orang guru, jadi dalam penelitian diambil semua populasi, sehingga merupakan penelitian populasi. Metode pengumpulan data menggunakan metode angket sebagai metode pokok, sedangkan metode observasi dan dokumentasi sebagai metode pelengkap, metode analisis data menggunakan analisis statistik dengan rumus Chi Square. Hasil penelitian bahwa nilai $x{ }^{2}$ hitung analisis lebih besar dari pada nilai $x^{2}$ tabel $(46,799>42,56)$, Karena $x^{2}$ hitung lebih besar dari harga $x{ }^{2}$ tabel, maka penelitian ini dikatakan signifikan. Hal ini berarti bahwa hipotesis nol ditolak dan hipotesis alternatif diterima, maka dapat ditarik kesimpulan bahwa: Ada Pengaruh Kepemimpinan Kharismatik Kepala Sekolah terhadap Motivasi Kerja Guru SMA Islam Al-Ashar NW Kayangan Batu Layar Kabupaten Lombok Barat, sehingga dapat disimpulkan "signifikan".
\end{abstract}

\section{Kata Kunci: Kepemimpinan Kharismatik, Motivasi Kerja Guru}

Keywords: Principal's Charismatic Leadership, Teachers' Work Motivation

The need for a study of teacher leadership and performance in the midst of the low quality of education in this country, is still very much needed. Principals in the future are demanded to be able to align the resources and potential of schools to achieve high performance towards better quality education. The purpose of this research is to determine the effect of the principal's charismatic leadership on the teachers' work motivation at Islamic High School NW Al-Ashar, Kayangan Batu Layar, West Lombok Regency. The population in this study is all teachers at Islamic High School NW Al-Ashar Kayangan Batu Layar West Lombok Regency totaling 30 teachers which is taken as the research sample. The data collection method uses the questionnaire method as the main method, while the observation and documentation method as a complementary method. The data then analyzed using Chi Square formula. The results of analysis shows that the obtained Chi Square value is 46,799 that greater than the value of Chi Square table 42.56. This comparison leads to the rejection of null hypothesis and the acceptance of the alternative hypothesis. So it can be concluded that the principal's charismatic leadership significantly affect teachers' work motivation at Islamic High School NW Al-Ashar.

\section{LATAR BELAKANG}

Kepemimpinan merupakan cara, perilaku dan sifat dari seorang pemimpin itu sendiri. Tidak terkecuali dengan kepemimpinan yang kharismatik yang merupakan cerminan dari sosok pemimpin tentunya banyak dipengaruhi dari beberapa faktor misalnya keturunan, penampilan maupun faktor lainnya.

Dalam suatu organisasi tentunya sangat dibutuhkan seseorang yang dapat mengelola dan mengendalikan organisasi tersebut untuk mencapai suatu tujuan. Pemimpin harus memiliki skill, pengalaman berorganisasi, visi dan misi yang jelas, dan kreativitas, tentunya kepribadian dan prilaku dari seorang pemimpin juga dapat menentukan iklim organisasi di dalamnya. Pemimpin merupakan orang yang menjadi panutan bagi bawahan-bawahannya, karena segala yang ada pada diri pemimpin dapat menjadi sorotan atau perhatian orang- orang disekitarnya. 
Pemimpin adalah seseorang yang mempunyai kemampuan untuk mempengaruhi prilaku orang lain dalam kerjanya dengan menggunakan kekuasaan. Seorang pemimpin adalah orang yang mampu mempengaruhi orang lain disekitarnya agar dapat mengikutinya. Sosok pemimpin yang diharapkan ialah orang yang dapat memberikan motivasi, arahan, saran, serta suri tauladan yang baik bagi orang-orang disekitarnya. Kepemimpinan adalah salah satu kekuatan penting dalam rangka pengelolaan, oleh sebab itu kemampuan seorang pemimpin secara efektif merupakan suatu kunci untuk menjadi seorang manajer yang efektif. Esensinya kepemimpinan adalah kepengikutan (followership), kemauan orang lain atau bawahan untuk mengikuti keinginan pemimpin, itulah yang menyebabkan seorang menjadi pemimpin (Atin, 2010: 65)

Terbentuknya jiwa kepemimpinan dimulai dari dunia pendidikan, oleh karena itu pendidikan dapat membantu memberikan gambaran akan hal yang positif terhadap perkembangan dan pembentukan karakteristik dalam kehidupan sehari-hari, misalnya dari cara beresikap, berfikir dan bertindak. Seorang pemimpin disekolah ialah kepala sekolah, kepala sekolah adalah pemimpin yang paling tersorot perannya didalam dunia pendidikan. Kepala sekolah adalah pemimpin yang dapat memberikan arahan serta saran dan motivasi kepada guru-guru dan staff disekolah untuk mencapai visi dan missi sekolah. Salah satu jenis kepemimpinan yang harus dimiliki oleh kepala sekolah adalah kepemimpina kharismatik.

Kepemimpinan kharismatik adalah kepemimpinan yang memiliki karakteristik yang khas yaitu daya tarik yang sangat memikat. Pemimpin kharismatik disini ialah seorang yang mampu memperoleh pengikut yang sangat besar, dan pengikutnya tidak selalu dapat menjelaskan secara kongkrit mengapa orang tersebut dikagumi. Kekayaan, umur, kesehatan, profil tidak dapat dipergunakan sebagai kriteria untuk karisma (Marshall dan Molly, 2010: 12).

Kepemimpinan kharismatik kepala sekolah sangat jarang ditemukan, namun sifat kharismatik ini sangat unik jika terdapat dari seseorang yang menjadi kepala sekolah akan lebih terlihat menarik, karna disisilain kepala sekolah bukan saja menjadi faktor utama untuk pendorong jalannya ruang lingkup manajemen sekolah, namun kepala sekolah ialah seseorang yang juga berpengaruh tinggi untuk dapat di contoh sikap, prilaku dan ucapannya oleh guru, staff dan siswa siswi di dalam ruang lingkup sekolah. Banyak fakta di lapangan yang menunjukkan masih rendahnya kinerja guru. Wawancara yang dilakukan penulis terhadap Guru di SMA Islam Al-Ashar NW Kayangan Batu Layar Kabupaten Lombok Barat memperkuat pendapat tentang rendahnya kinerja guru. Hasil wawancara menunjukkan beberapa gambaran mengenai kondisi yang dimaksud, antara lain guru tidak membuat perencanaan yang memadai dalam menjalankan tugas mengajar, tidak menyusun RPP, membuat RPP hanya untuk memenuhi syarat administrasi mengajar, dan tidak mempersiapkan media pembelajaran. Ada juga guru yang mengajar dengan acuan buku. Semua fakta di atas menggambarkan masih rendahnya kinerja guru. Guru sebagai insan yang mengemban tugas profesional, kinerjanya masih perlu mendapatkan perhatian. Dalam sebuah lembaga pendidikan, kepala sekolah sangat berperan dalam menggerakkan berbagai komponen di sekolah yang dipimpinnya. Menurut Siagian (2013: 34), bahwa peran kepala sekolah pada abad 21, lebih banyak berpartisipasi secara tidak langsung pada pembelajaran, yaitu mencapai angka sebesar 91\%. Hal ini menunjukkan bahwa kepemimpinan kepala sekolah memiliki andil yang cukup besar dalam mendukung proses pembelajaran yang dilakukan oleh guru dan hal tersebut akan berpengaruh pada peningkatan mutu pendidikan di sekolah.

Kepemimpinan kharismatik memegang peranan sangat penting dalam mendorong upaya reformasi sekolah. Pengelolaan lembaga sekolah tidak dapat dipisahkan dari gaya 
kepemimpinan kepala sekolah dalam menjalankan proses pendidikan. Selain itu, pendidikan di sekolah juga dipengaruhi oleh kompetensi manajerial kepala sekolah dalam mengelola setiap komponen pada lembaga yang dipimpinnya. Kompetensi yang dimaksud berkaitan dengan pengetahuan dan pemahamaman tentang manajemen, serta tugas yang dibebankan kepada kepala sebagai manajer lembaga sekolah (Mulyasa, 2013: 65).

Kebutuhan kajian tentang kepemimpinan dan kinerja guru di tengah-tengah rendahnya kualitas pendidikan di negeri ini, masih sangat diperlukan. Kepala sekolah di masa mendatang dituntut mampu menyelaraskan sumberdaya dan potensi sekolah untuk mencapai kinerja yang tinggi menuju kualitas pendidikan yang lebih baik. Hal ini merupakan aspek yang menarik untuk diteliti. Hal inilah yang membuat peneliti tertarik untuk meneliti tentang Pengaruh Kepemimpinan Kharismatik Kepala Sekolah terhadap Motivasi Kerja Guru SMA Islam AlAshar NW Kayangan Batu Layar Kabupaten Lombok Barat.

\section{KAJIAN PUSTAKA}

\section{Kepemimpinan Kharismatik}

Kepemimpinan kharismatik adalah kepemimpinan seseorang yang berkharisma memiliki daya pikat yang luar biasa. Bahkan kadang dianggap memiliki kemampuan supranatural (Danim, 2010: 32). Ahli lain mengungkapkan bahwa kepemimpinan kharismatik adalah orang yang penuh energi alami dan positif dilingkungannya yang menginspirasi orang lain dan mendorong mereka untuk menjadi yang terbaik (Atin, 2010: 12).

Artinya seseorang yang memiliki kharisma berarti orang yang memiliki kelebihan, perbedaan dan keistimewaan dari pada yang lain. Seorang pemimpin kharismatik adalah orang yang penuh energi alami dan positif dilingkungannya. Jika seseorang secara alami kharismatik, dia menjadi sangat beruntung. Ini adalah suatu sifat yang tidak begitu mudah dipelajari. Pemimpin kharismatik menginspirasi orang lain dan mendorong mereka untuk menjadi yang terbaik (Engkoswara dan Komariah, 2012: 23).

Pemimpin itu sebagai seorang yang memiliki sifat-sifat kepribadian yang penting dan luhur. Pemimpin kharismatik pun esensinya adalah pemimpin transformasi. Pemimpin jenis ini selayak nya sengaja diturunkan di alam ini dan sering kali dibandingkan dengan pahlawan.

Pemimpin kharismatik adalah suatu anugrah yang dapat dimiliki seseorang, karena pemimpin kharismatik memiliki rasa percaya diri tinggi sehingga dia mampu untuk mempengaruhi orang lain yang ada disekitarnya. Selain memiliki rasa percaya diri, pemimpin kharismatik juga memiliki kemampuan dalam berkomunikasi dengan baik terhadap orang lain yang ada disekitarnya, sehingga dia selalu dapat memberikan perubahan-perubahan dalam kepemimpinannya (Musfah, 2015: 12). Yang tampak dari pemimpin kharismatik adalah pemimpin yang mempunyai daya tarik yang amat besar dan karena pada umumnya mempunyai pengikut yang jumlahnya sangat besar, meskipun para pengikut itu sering pula tidak dapat menjelaskan mengapa mereka menjadi pengikut pemimpin itu

Kharisma adalah kualitas khusus yang dimiliki oleh seseorang, dimana ia berfungsi semacam magnet, tetapi sebenarnya terdiri dari banyak sifat. Salah satu unsur yang paling penting dari sifat itu adalah kepercayaan diri (Syagala, 2012: 12). Seorang pemimpin kharismatik adalah seorang yang dikagumi oleh banyak pengikut, meskipun para pengikut tidak selalu dapat menjelaskan secara kongkret mengapa orang tersebut dikagumi”. Menurut dari beberapa teori yang mengungkapkan tentang kepemimpinan kharismatik, bahwa seorang pemimpin kharismatik memanglah hal sangat istimewa, sehingga para pengikutnya tidak pernah mengerti apa alasan yang lebih kuat mereka untuk tetap mengikuti pemimpin itu. Hal ini memberikan gambaran kembali bahwa pemimpin kharismatik memang orang yang mampu memberikan kebaikan-kebaikan bagi orang-orang disekitarnya (Usman, 2010: 54). 
Berdasarkan pendapat para ahli di atas, maka yang dimaksud dengan kepemimpinan kharismatik dalam penelitian ini adalah orang yang memiliki rasa percaya diri yang tinggi, memiliki visi misi yang benar benar sudah matang, dapat bersikap tegas dalam memberikan pekerjaan kepada bawahannya dan memiliki wibawa yang tidak dibuat buat oleh seorang kepala sekolah.

\section{Motivasi Kerja}

Motif seringkali diistilahkan sebagai dorongan. Dorongan atau tenaga tersebut merupakan gerak jiwa dan jasmani untuk berbuat, sehingga motif tersebut merupakan driving force yang menggerakkan manusia untuk bertingkah laku dan didalam perbuatannya itu mempunyai tujuan tertentu (As'ad, 2015: 45). Motivasi secara sederhana dapat diartikan "Motivating" yang secara implisit berarti bahwa pimpinan suatu organisasi berada di tengahtengah bawahannya, dengan demikian dapat memberikan bimbingan, instruksi, nasehat dan koreksi jika diperlukan (Siagian, 2015: 129). Sedangkan pendapat lain mengatakan bahwa motivasi adalah keinginan yang terdapat pada seorang individu yang merangsang untuk melakukan tindakan (Winardi, 2000: 312). Motivasi adalah dorongan yang ada dalam diri manusia yang menyebabkan ia melakukan sesuatu (Wursanto, 2017: 132).

Dalam kehidupan manusia selalu mengadakan bermacam-macam aktifitas. Salah satu aktivitas itu diwujudkan dalam gerakan-gerakan yang dinamakan kerja. Menurut As'ad (2015: 46) bekerja mengandung arti melaksanakan suatu tugas yang diakhiri dengan buah karya yang dapat dinikmati oleh manusia yang bersangkutan. Faktor pendorong penting yang menyebabkan manusia bekerja, adalah adanya kebutuhan yang harus dipenuhi. Aktifitas dalam kerja mengandung unsur suatu kegiatan sosial, menghasilkan sesuatu, dan pada akhirnya bertujuan untuk memenuhi kebutuhannya. Namun demikian dibalik dari tujuan yang tidak langsung tersebut orang bekerja juga untuk mendapatkan imbalan, upah atau gaji dari hasil kerjanya. Jadi pada hakekatnya orang bekerja, tidak saja untuk mempertahankan kelangsungan hidupnya tapi juga untuk mencapai taraf hidup yang lebih baik. Menurut Smith dan Wakeley (As'ad, 2015: 47) menyatakan bahwa seseorang didorong untuk beraktivitas karena dia berharap bahwa hal ini akan membawa pada keadaan yang lebih memuaskan daripada keadaaan sekarang. Pendapat dari Gilmer (As'ad, 2015: 47), bahwa bekerja itu merupakan proses fisik maupun mental manusia dalam mencapai tujuannya. Dari beberapa pendapat di atas dapat disimpulkan bahwa bekerja adalah aktivitas manusia baik fisik maupun mental yang dasarnya mempunyai tujuan yaitu untuk mendapatkan kepuasan. Ini tidak berarti bahwa semua aktivitas itu adalah bekerja, hal ini tergantung pada motivasi yang mendasari dilakukannya aktivitas tersebut.

Dari berbagai pendapat mengenai definisi motivasi dan definisi kerja di atas dapat disimpulkan bahwa motivasi kerja adalah dorongan yang tumbuh dalam diri seseorang, baik yang berasal dari dalam dan luar dirinya untuk melakukan suatu pekerjaan dengan semangat tinggi menggunakan semua mendapatkan hasil kerja sehingga mencapai kepuasan sesuai dengan keinginannya. Untuk dapat memberikan hasil kerja yang berkualitas dan berkuantitas maka seorang pegawai/ guru membutuhkan motivasi kerja dalam dirinya yang akan berpengaruh terhadap semangat kerjanya sehingga meningkatkan kinerjanya. Telah lama diketahui bahwa manusia adalah makhluk sosial. Sebagai makhluk sosial ia membutuhkan rasa sayang, pengakuan keberadaan, rasa ingin memiliki berbagai kebutuhan tersebut, manusia bekerja dan berusaha dengan sekuat tenaga untuk memenuhi keinginan itu.

Berdasarkan pendapat para ahli di atas, maka yang dimaksud dengan motivasi kerja dalam penelitian ini adalah dorongan yang tumbuh dalam diri guru, baik yang berasal dari dalam dan luar dirinya untuk melakukan suatu pekerjaan dengan semangat tinggi 
menggunakan semua kemampuan dan ketrampilan yang dimiliki.

\section{Pengaruh Kepemimpinan Kharismatik Kepala Sekolah terhadap Motivasi Kerja Guru}

Kaktor keberhasilan pendidikan dalam pengelolaannya, tidak terlepas dari peran kepemimpinan yakni kepala sekolah. Kepemimpinan adalah kemampuan mempengaruhi, mendorong, mengajak, orang lain untuk mencapai tujuan tertentu. Kepemimpinan dalam penelitian ini adalah kepemimpinan kharismatik. Pemimpin yang berkarisma sering dikatakan pandai dalam menyuarakan ideologinya yang berhubungan dengan tujuan organisasi, sehingga dapat menciptakan aspirasi bersama para karyawan. Jiwa kepemimpinan karismatik yang dimiliki oleh seseorang akan memberikan contoh-contoh perilaku yang baik agar dapat ditiru oleh para karyawannya, dan mampu memotivasi para karyawannya dengan memberikan beberapa pujian. Hal ini akan senantiasa menumbuhkan rasa percaya diri oleh karyawan dan secara tidak langsung menghidupkan jiwa karismatik seorang pemimpin.

Selanjutnya faktor motivasi kerja guru, sebagai salah satu konsep, motivasi banyak menarik perhatian berbagai pihak tidak terkecuali dalam bidang pendidikan. Dalam hal ini salah satu hal yang dianggap penting adalah motivasi kerjaguru. Dimana guru punya dorongan dalam dirinya untuk mengatasi tantangan dan hambatan dalam mencapai tujuan. Motivasi kerja sebagai keinginan untuk mengerahkan sekuat tenaga agar tercapai tujuan yang terorganisasi, dilakukan dengan kemampuan yang dimiliki untuk memenuhi kebutuhan individu atau organisasi.

Kepemimpinan kharismatik memiliki pengaruh terhadap motivasi kerja guru. Kepemimpinan kharismatik kepala sekolah berpengaruh positif terhadap kinerja guru.

\section{METODE PENELITIAN}

Metode penelitian pada dasarnya merupakan suatu cara untuk memperoleh atau memecahkan permasalahan yang dihadapi. Metode penelitian merupakan salah satu faktor pendukung keberhasilan penelitian karena metode penelitian merupakan jalan untuk menemukan, mengembangkan dan menguji kebenaran ilmu pengetahuan manusia secara ilmiah.

Dalam suatu penelitian ilmiah dikenal dua pendekatan yaitu pendekatan eksperimen dan pendekatan empiris/deskriptif. Pendekatan Eksperimen adalah: "Dimana obyek yang akan diteliti segaja dirancang atau dibuat/dimanipulasi dulu baru dilakukan percobaan di lapangan, sedangkan pendekatan empiris/diskriptif adalah pendekatan dimana obyek yang akan di teliti sudah ada secara wajar di lapangan" (Sugiyono, 2007: 17). Dalam penelitian ini, pendekatan yang digunakan adalah pendekatan empiris, karena gejala yang akan di teliti sudah ada secara wajar, peneliti tidak menimbulkan gejala baru tentang pengaruh kepemimpinan kharismatik kepala sekolah terhadap motivasi kerja guru SMA Islam Al-Ashar NW Kayangan Batu Layar Kabupaten Lombok Barat Tahun. Adapun gambaran rancangan penelitiannya adalah sebagi berikut : 


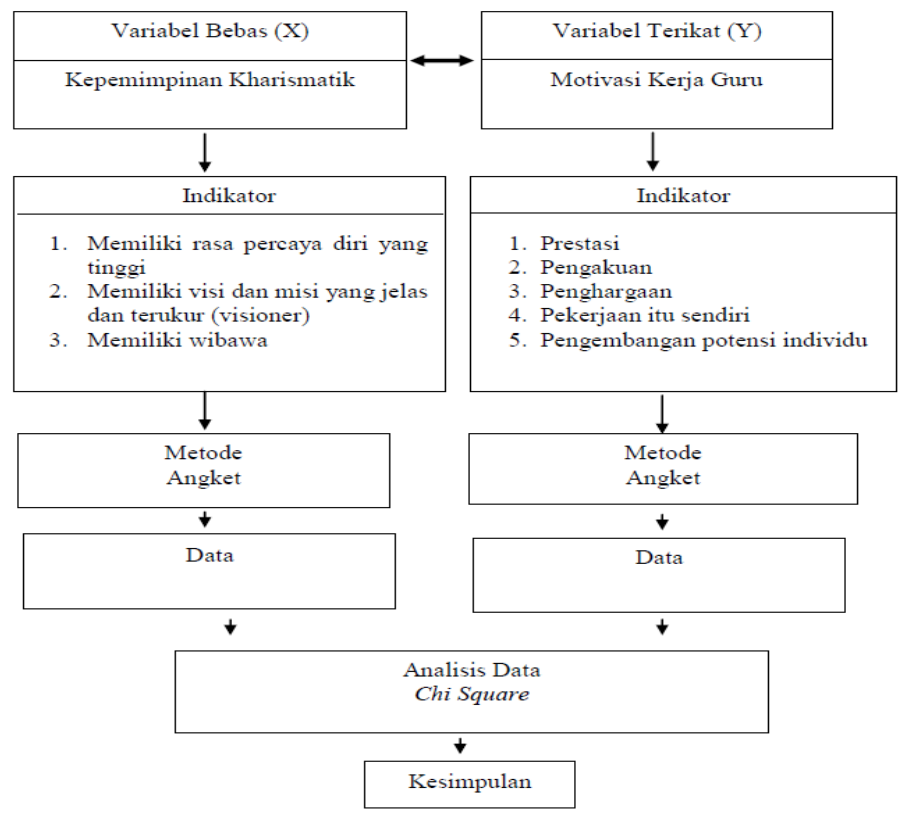

\section{Gambar 3.1. Rancangan Penelitian}

Penelitian ini merupakan penelitian populasi karena menggunakan seluruh populasi sebagai sampel yang berjumlah 30 orang guru. Dalam buku Statistika dan Probalitas dijelaskan "Mengolah data berarti mengatur atau mengorganisir. Mengatur dan mengorganisir berarti menggolongkan data yang diperlukan dalam penelitian secara sistematis dan rapi menurut aturan tertentu, sehingga dapat dengan mudah dan cepat dimengerti serta dapat memilih data yang tepat dan berkaitan dengan masalah yang diteliti" (Budiono, dkk, 2004: 19). Dalam penelitian ini analisis data yang dilakukan setelah data terkumpul, maka langkah selanjutnya adalah: 1) Mengkode Data: Mengkode data adalah memberikan simbol yang berupa angka pada setiap jawaban yang diperoleh; 2) Memberikan Skor: Memberikan skor adalah memberikan skor berdasarkan jawaban yang diperoleh; 3) Mentabulasi Data: Tabulasi data adalah memasukan data kedalam tabel sehingga data itu dapat menggambarkan apa yang diungkapkan oleh responden secara menyeluruh dan data ini mudah dipahami; 4) Melaksanakan analisa data dengan rumus Chi Square.

Adapun rumus Chi Square sebagai berikut:

$$
\mathrm{X}^{2}=\sum \frac{(\mathrm{fo}-\mathrm{fh}) 2}{\mathrm{fh}}
$$

Keterangan :

$\mathrm{X}^{2}=$ Harga Chi-Kuadrat yang dicari

$\mathrm{f}_{\mathrm{o}}=$ frekuensi yang diperoleh berdasarkan data

$\mathrm{f}_{\mathrm{h}}=$ frekuensi yang diharapkan

Adapun Langkah-Iangkah Menganalisa Data sebagai berikut:

1. Merumuskan hipotesis nol (Ho)

2. Membuat tabel kerja

3. Memasukkan data dalam rumus

4. Mencari nilai Koefisien Chi Square.

5. Menarik kesimpulan analisis 
(Sugiyono, 2007 : 229-230).

\section{HASIL DAN PEMBAHASAN}

Penelitian ini dilakukan selama 1 bulan dengan mengumpulkan data pengaruh kepemimpinan kharismatik kepala sekolah terhadap motivasi kerja guru SMA Islam Al-Ashar NW Kayangan Batu Layar Kabupaten Lombok Barat yang diambil melalui angket.

Adapun langkah-langkah yang ditempuh dalam pengujian hipotesis adalah sebagai berikut:

1. Merumuskan Hipotesis Nihil (Ho)

Dalam bab I diajukan hipotesis alternatif (Ha) yang berbunyi Ada Pengaruh Kepemimpinan Kharismatik Kepala Sekolah terhadap Motivasi Kerja Guru SMA Islam Al-Ashar NW Kayangan Batu Layar Kabupaten Lombok Barat Tahun. Maka perlu diubah terlebih dahulu kedalam hipotesis nol (Ho) sehingga berbunyi Tidak ada Pengaruh Kepemimpinan Kharismatik Kepala Sekolah terhadap Motivasi Kerja Guru SMA Islam Al-Ashar NW Kayangan Batu Layar Kabupaten Lombok Barat.

2. Membuat Tabel Kerja

Tabel 3.1 Tabel Kerja Pengujian Hipotesis Pengaruh Kepemimpinan Kharismatik Kepala Sekolah terhadap Motivasi Kerja Guru SMA Islam Al-Ashar NW Kayangan Batu Layar Kabupaten Lombok Barat.

\begin{tabular}{|c|c|c|c|c|c|}
\hline No & $\boldsymbol{f 0}$ & $\boldsymbol{F h}$ & $\boldsymbol{f 0}-\boldsymbol{f h}$ & $(\boldsymbol{f 0}-\boldsymbol{f h})^{\mathbf{2}}$ & $(\boldsymbol{f 0}-\boldsymbol{f h})^{\mathbf{2}} \mathbf{f h}$ \\
\hline $\mathbf{( 1 )}$ & $\mathbf{( 2 )}$ & $\mathbf{( 3 )}$ & $\mathbf{( 4 )}$ & $\mathbf{( 5 )}$ & $(\mathbf{6})$ \\
\hline 1 & 55 & 47 & 8 & 64 & 1,3617 \\
\hline 2 & 54 & 52 & 2 & 4 & 0,07692 \\
\hline 3 & 52 & 48 & 4 & 16 & 0,33333 \\
\hline 4 & 53 & 51 & 2 & 4 & 0,07843 \\
\hline 5 & 53 & 49 & 4 & 16 & 0,32653 \\
\hline 6 & 55 & 55 & 0 & 0 & 0 \\
\hline 7 & 54 & 50 & 4 & 16 & 0,32 \\
\hline 8 & 51 & 51 & 0 & 0 & 0 \\
\hline 9 & 47 & 46 & 1 & 1 & 0,02174 \\
\hline 10 & 46 & 50 & -4 & 16 & 0,32 \\
\hline 11 & 45 & 51 & -6 & 36 & 0,70588 \\
\hline 12 & 47 & 51 & -4 & 16 & 0,31373 \\
\hline 13 & 45 & 49 & -4 & 16 & 0,32653 \\
\hline 14 & 52 & 52 & 0 & 0 & 0 \\
\hline 15 & 50 & 54 & -4 & 16 & 0,2963 \\
\hline 16 & 53 & 55 & -2 & 4 & 0,07273 \\
\hline 17 & 49 & 51 & -2 & 4 & 0,07843 \\
\hline 18 & 48 & 50 & -2 & 4 & 0,08 \\
\hline 19 & 55 & 52 & 3 & 9 & 0,17308 \\
\hline 20 & 55 & 55 & 0 & 0 & 0 \\
\hline 21 & 54 & 54 & 0 & 0 & 0 \\
\hline 22 & 54 & 54 & 0 & 0 & 0 \\
\hline 23 & 55 & 55 & 0 & 0 & 0 \\
\hline 24 & 55 & 55 & 0 & 0 & 0 \\
\hline & & & & & \\
\hline
\end{tabular}




\begin{tabular}{|c|c|c|c|c|c|}
\hline 25 & 34 & 53 & -19 & 361 & 6,81132 \\
\hline 26 & 32 & 55 & -23 & 529 & 9,61818 \\
\hline 27 & 35 & 54 & -19 & 361 & 6,68519 \\
\hline 28 & 33 & 55 & -22 & 484 & 8,8 \\
\hline 29 & 32 & 55 & -23 & 529 & 9,61818 \\
\hline 30 & 38 & 42 & -4 & 16 & 0,38095 \\
\hline Jumlah & 1441 & 1551 & -110 & 2522 & 46,7992 \\
\hline
\end{tabular}

3. Memasukan Angka ke dalam Rumus

Melaksanakan analisa data dengan rumus Chi Square (Sugiyono, 2007: 229-230). Berdasarkan Tabel di atas, maka diperoleh nilai $x^{2}$ hitung sebesar 46,799.

4. Menguji Nilai Chi Square

Sesuai dengan hasil perhitungan Chi Square yang diperoleh melalui analisis ternyata nilai diperoleh $=46,799$ sedangkan nilai $x^{2}$ dalam tabel dengan derajat bebas $(\mathrm{N}-1)=30-1=29$ dengan taraf signifikansi $5 \%=42,56$, dengan demikian bahwa nilai $x^{2}$ hitung analisis lebih besar dari pada nilai $x^{2}$ tabel $(46,799>42,56)$. Hal ini berarti hipotesis nol ditolak dan hipotsis alternatif diterima.

5. Menarik Kesimpulan

Dari hasil uji Chi Square menunjukkan nilai $x{ }^{2}$ hitung sebesar 46,799 maka berdasarkan taraf signifikansi $5 \%$ dan $\mathrm{db}=29$ ternyata besarnya angka batas penolakan hipotesis nol yang dinyatakan dalam tabel distribusi $x^{2}$ tabel adalah 42,56.

Kenyataan ini menunjukkan bahwa nilai $x^{2}$ hitung analisis lebih besar dari pada nilai $x^{2}$ tabel $(46,799>42,56)$, Karena $x^{2}$ hitung lebih besar dari harga $x^{2}$ tabel, maka penelitian ini dikatakan signifikan. Hal ini berarti bahwa hipotesis nol ditolak dan hipotesis alternatif diterima, maka dapat ditarik kesimpulan bahwa: Ada Pengaruh Kepemimpinan Kharismatik Kepala Sekolah terhadap Motivasi Kerja Guru SMA Islam Al-Ashar NW Kayangan Batu Layar Kabupaten Lombok Barat.

Hasil penelitian menunjukkan bahwa nilai $x{ }^{2}$ hitung analisis lebih besar dari pada nilai $x{ }^{2}$ tabel $(46,799>42,56)$, Karena $x{ }^{2}$ hitung lebih besar dari harga $x{ }^{2}$ tabel, maka penelitian ini dikatakan signifikan. Hal ini berarti bahwa hipotesis nol ditolak dan hipotesis alternatif diterima, maka dapat ditarik kesimpulan bahwa: Ada Pengaruh Kepemimpinan Kharismatik Kepala Sekolah terhadap Motivasi Kerja Guru SMA Islam Al-Ashar NW Kayangan Batu Layar Kabupaten Lombok Barat.

Berdasarkan temuan dalam penelitian ini jelas bahwa kepemimpinan kharismatik kepala sekolah sangat berpengaruh terhadap kinerja guru karena kemampuan guru dalam meningkatkan kinerjanya dikarenakan dengan adanya kemampuan kepala sekolah dalam menjalin hubungan kerjasama dan koordinasi dengan berbagai pihak yang didasari oleh adaya suatu kebijakan dari pimpinan pendidikan yang dapat memberikan kesempatan kepada guru untuk mengembangkan mutu kinerjanya. Karena itulah kepala sekolah sebagai pimpinan sekolah hendaknya mengembangkan mutu kinerja guru secara komprehensif dan kontinu sebagai satu keharusan dalam kegiatan sekolah.

\section{KESIMPULAN}

Setelah dilakukan penelitian dan proses analisa data menunjukkan bahwa nilai $x^{2}$ hitung analisis lebih besar dari pada nilai $x^{2}$ tabel $(46,799>42,56)$, Karena $x^{2}$ hitung lebih besar dari harga $x^{2}$ tabel, maka penelitian ini dikatakan signifikan. Hal ini berarti bahwa hipotesis nol ditolak dan hipotesis alternatif diterima, maka dapat ditarik kesimpulan bahwa: Ada 
Pengaruh Kepemimpinan Kharismatik Kepala Sekolah terhadap Motivasi Kerja Guru SMA Islam Al-Ashar NW Kayangan Batu Layar Kabupaten Lombok Barat, sehingga dapat disimpulkan "signifikan".

\section{DAFTAR PUSTAKA}

Arikunto, S. 2006. Prosedur Penelitian Suatu Pendekatan Praktek. Jakarta: Rineka Cipta. Alfian, Alfan. 2009. Menjadi Pemimpin Politik. Jakarta: Gramedia Pustaka Utama,

Atin Kurniatin. 2010. "Gaya Kepemimpinan Demokratis Kepala Sekolah di SMAN 8 Kabupaten Tangerang". Jakarta: Skripsi UIN Syarif Hidayatullah Jakarta.

Budiono, dkk. 2004. Metodelogi Research. Bandung: CV. Tarsito.

Danim, Sudarwan. 2010. Kepemimpinan Pendidikan. Bandung: Alfabeta.

Engkoswara dan Komariah, Aan. 2012. Administrasi Pendidikan. Bandung: Alfabeta.

Marshall dan Molly. 2011. Prinsip-Prinsip Kepemimpinan. Jakarta: Erlangga.

Mulyasa. 2013. (a). Manajemenn dan Kepemimpinan Kepala Sekolah. Jakarta: Bumi Aksara.

Mulyasa. 2013. (b). Manajemen Pendidikan Karakter. Jakarta: Bumi Aksara.

Musfah, Jejen. 2015. Manajemen Pendidikan Teori, Kebijakandan Praktis. Jakarta: Kencana.

Sagala, Syaiful. 2013. Administrasi Pendidikan Konteporer, Bandung: Alfabeta.

Siagian, Sondang P. 2013. (b). Teori dan Praktek Kepemimpinan. Jakarta: PT Rineka Cipta.

Sugiyono. 2007. Statsistik Untuk Penelitia. Bandung: CV. Alfabeta.

Syagala, Syaiful. 2012. Administrasi Pendidikan Konteporer. Bandung: Alfabeta.

Usman, Husaini. 2010. Manajemen Teori Praktik dan Riset Pendidikan. Edisi II, Jakarta: Bumi Aksara. 